\title{
НАУКОВО-МЕТОДИЧНІ ОСНОВИ ВИКЛАДАННЯ ФАРМАКОЛОГІЇ ЛІКАРСЬКИХ ЗАСОБІВ, ЩО ВПЛИВАЮТЬ НА ПРОЦЕСИ ЗГОРТАННЯ KPOBI
}

\author{
Н. І. Волощук, О. М. Денисюк, В. В. Данильчук, С. В. Біговщиць \\ Вінницький національний медичний університет імені М. I. Пирогова
}

\section{SCIENTIFIC AND METHODICAL FUNDAMENTALS OF TEACHING PHARMACOLOGY OF DRUGS ACTING ON BLOOD COAGULATION}

\author{
N. I. Voloshchuk, O. M. Denysiuk, V. V. Danylchuk, S. V. Bihovshchyts \\ M. Pyrohov Vinnytsia National Medical University
}

\begin{abstract}
Швидкий розвиток фармакологічної науки та поява нових лікарських засобів вимагають постійної зміни програмного матеріалу і вдосконалення методичних підходів до викладання цього матеріалу майбутнім лікарям. Мета роботи - виділити підходи до викладання одного з найбільш складних та важливих розділів фармакології - “Засоби, що впливають на згортання крові” студентам 3-го курсу медичного факультету й 2-го курсу стоматологічного факультету. Аналіз педагогічного досвіду викладачів кафедри фармакології Вінницького національного медичного університету та літературних даних показав, що оптимальним є комплексний підхід. Він включає надання інформації викладачем на лекційних і практичних заняттях (пояснювально-ілюстративний метод), активний самостійний пошук інформації студентом (репродуктивний, проблемний, евристичний методи), а також інноваційні та нетрадиційні методи навчання (наприклад, фармакологічна вікторина). Принцип “від простого до складного” при збереженні послідовності дидактичних підходів викладання, а також правильна організація аудиторної та позааудиторної самостійної роботи студентів дозволяють отримати стабільні і глибокі знання та вміння, навчити його працювати самостійно.
\end{abstract}

The rapid development of pharmacological science and the emergence of new drugs requires constant change program material and improvement of methodical approaches to teaching of future doctors. The aim of the study: to identify approaches to teaching one of the most difficult and important section of pharmacology - "Drugs acting on blood coagulation" - for students of the 3rd course of Medical Faculty and 2nd course of Stomatological Faculty. Analysis of teaching experience of teachers of the Pharmacology Department of M. Pyrohov Vinnytsia National Medical University and literature data showed that the best is a complex approach. It includes providing information on lectures and practical classes (explanatory, illustrative method), active independent search information by students (reproductive, problem, heuristic methods) and interactive methods (pharmacological quiz). The principle "from simple to complex" when saving a sequence of didactic approaches to teaching and correct organization of independent work of students allows to get stable and deep knowledge and skills, teach him to work independently.

Вступ. В останні роки в Україні відбувається реформа і модернізація вищої школи, висуваються підвищені вимоги до якості освіти, в т. ч. і медичної $[1,2]$. Значне зростання змісту наукової інформації вимагає від студентів засвоєння ії у величезних обсягах. Постійно зростаюча кількість препаратів різних груп, поява нових груп лікарських засобів 3 принципово відмінними механізмами дії зумовлюють необхідність постійного моніторування обсягу програмного матеріалу, а також пошук та розробку нових методичних підходів до покращення засвоєння цього матеріалу майбутніми лікарями. Так, одним 3 найбільш складних та важливих розділів науки про лікознавство $є$ “Фармакологія засобів, що впливають на згортання крові”. Необхідність вивчення цієї групи засобів не викликає жодних сумнівів, особливо з точки зору обставин, у яких перебуває наша країна.

Основна частина. У своій роботі викладацький колектив кафедри фармакології ВНМУ ім. М. І. Пирогова використовує комплексний підхід до викладання, в т. ч. і при викладанні зазначеної теми, що включає як надання інформації викладачем на лекційних і практичних заняттях, так і активний їі пошук студентом при підготовці до занять, опрацюванні тем, що винесені на самостійну позааудиторну роботу та при виконанні студентської науково-дослідної роботи. Отже, ми використо-

( Н. І. Волощук, О. М. Денисюк, В. В. Данильчук, С. В. Біговщиць 
вуємо наступні методичні підходи, що сприяють оптимізації вивчення даної теми:

1. В рамках пояснювально-ілюстративного методу навчання (студент отримує знання в готовому вигляді) широкого використання набуває візуалізація матеріалу - представлення даних у вигляді зображення з метою максимальної зручності їх розуміння.

Суттєва роль відведена лекції в супроводі мультимедійної презентації. На сьогодні саме мультимедійна презентація $\epsilon$ найсучаснішим способом візуалізації, який містить текстові матеріали, фотографії, малюнки, слайд-шоу, відеофрагменти і анімацію, активуючи не тільки слухове, а й зорове сприйняття інформації. Подібне подання матеріалу допомагає сформувати у студента початкове уявлення про ті чи інші групи препаратів. Значущість лекції сьогодні все більше зростає, враховуючи невпинний і швидкий розвиток фармакологічної науки, за яким не може встигнути створення і видання нових підручників та посібників. Так, до групи антигеморагічних препаратів, що включає в себе коагулянти, інгібітори фібринолізу, агреганти, ангіопротектори тощо, за останні 2 роки додалась відносно нова група лікарських засобів (гемостопи), що представлена на сучасному фармацевтичному ринку препаратами на основі хітозану (Celox, ChitoGaze), на основі цеоліту (Quikclot, Гемостоп) та інших груп (Кровоспас). Вони мають принципово інший механізм дії, показання та протипоказання до застосування. На сьогодні ці засоби $\epsilon$ вкрай вживаними препаратами в зоні проведення ATO, адже використовуються для швидкої зупинки кровотечі при різних видах поранень, що, у свою чергу, може врятувати життя військових. Тому лікар повинен знати ці препарати і вміти їх використовувати. Та, на жаль, у підручниках дані про них відсутні. Тому ми включили основні відомості про гемостопи в мультимедійну презентацію лекції для студентів. Особливо привернули увагу слухачів, а отже, сприяли запам'ятовуванню матеріалу, дуже яскраві фотографії форм випуску гемостопів та їх безпосереднього застосування.

Ще одним методом візуалізації, який активно використовують співробітники кафедри фармакології ВНМУ ім. М. І. Пирогова, є представлення навчальної інформації у вигляді блок-схем, структурно-логічних схем і т. п. Такий спосіб візуального відображення допомагає систематизувати інформацію, проводити паралелі між окремими даними, дозво- ляє швидше і міцніше запам'ятовувати інформацію, адже така наочність спирається на структуру і асоціативні зв'язки, характерні для довготривалої пам'яті людини. Враховуючи те, що основна маса клінічних дисциплін вивчається, починаючи з 4-го курсу, студентам 3-го курсу медичного факультету і тим більше студентам 2-го курсу стоматологічного факультету важко за одне заняття зрозуміти i запам'ятати весь програмний матеріал, який містить інформацію про значну кількість лікарських засобів. Тому на основі літературних даних та навчальних посібників нами розроблено схематичну класифікацію лікарських засобів, що впливають на зсідання крові відповідно до різних точок прикладання дії препаратів та основних механізмів їх дії із зазначенням форми їх випуску. Таке схематичне викладення інформації сприяє полегшенню засво$є н$ нн необхідного матеріалу. Крім того, це дає змогу студенту краще зрозуміти клінічну класифікацію цих лікарських засобів, яка також представлена на схемі, що, у свою чергу, допомагає перейти від теоретичного етапу засвоєння знань до практичного їх застосування у майбутній професійній діяльності - призначення того чи іншого препарату з урахуванням знань його механізму дії.

2. При методично грамотному використанні методів візуалізації відбувається перехід студентів на більш високі рівні пізнавальної діяльності, коли оволодіння предметним змістом здійснюється 3 елементами евристики. Евристичний метод передбачає конструювання студентами своїх знань, використання їх у різних професійних ситуаціях [3].

Так, у рамках репродуктивного та проблемного методів навчання на практичних заняттях викладачі використовують ситуаційні задачі та завдання 3 частково відсутньою інформацією, вирішення яких вимагає достатнього рівня знань. Мета такого навчання полягає у формуванні у студентів здатності самостійно аналізувати представлені дані та застосовувати отримані знання з фармакокінетики та фармакодинаміки лікарських засобів на теоретичних моделях різних клінічних ситуацій. Це сприяє закріпленню навчального матеріалу, створює додаткові мотивації до систематичного навчання, а тому покращує підготовку майбутніх фахівців. Правильно складена ситуаційна задача наближає студента до його майбутньої практичної діяльності.

3. Та найбільшу увагу в методології викладання на сьогодні приділяють самостійній роботі студен- 
та в рамках проблемного та дослідницького методів навчання. В умовах дії нової редакції Закону України “Про вищу освіту” [4] відбулись зміни в навчальних планах для багатьох дисциплін, у тому числі і фармакології, згідно з якими зменшилась кількість аудиторних занять та збільшилась кількість годин для самостійної роботи студента. Слід визнати, що самостійна робота студентів є не просто важливою формою пізнавального процесу, а i його основою, тому що тільки ті знання, до яких людина прийшла самостійно, стає дійсно міцним надбанням. Студент переводиться з пасивного споживача знань в активного їх творця, що вміє сформулювати проблему, проаналізувати шляхи іï вирішення, знайти оптимальний результат і довести його правильність. На кафедрі фармакології ВНМУ ім. М. І. Пирогова позааудиторна самостійна робота реалізується у реферативних доповідях на практичних заняттях, підготовці матеріалів та виступах на засіданнях студентського наукового гуртка кафедри, презентації реферативних та стендових доповідей на студентській науковій конференції. Останнім часом все більше студентів охоче залучаються до такої роботи. Так, на студентській науковій конференції ВНМУ “Перший крок в науку - 2016” були представлені доповіді, які більш детально, з глибоким аналізом літератури висвітлювали окремі питання фармакології, в тому числі і з теми “Засоби, що впливають на систему згортання крові”, а саме: “Місце і роль реваскуляризаційної терапії при судинних катастрофах”, “Тромболітична терапія. Тромболізис” та “Якщо пологи ускладнились кровотечею...” При підготовці до конференції студентами було опрацьовано та проаналізовано велику кількість літератури, структуровано та систематизовано отримані дані, знайдені цікаві факти, які сприяють запам’ятовуванню інформації. Крім того, студенти творчо та, навіть, креативно підійшли до візуального оформлення своїх доповідей. Безперечно, участь у конференції формує професійну самостійність студента, підвищує його інтелектуальний рівень, формує позитивну мотивацію до навчання. Крім того, за традицією нашої кафедри такі презентації залишаються вивішеними в навчальних кімнатах до кінця навчального року, і будь-який студент має змогу ознайомитися з викладеним матеріалом.

4. Альтернативні методи навчання.

Важливу роль в удосконаленні навчального процесу, на наш погляд, відіграє впровадження альтернативних методів навчально-пізнавальної діяльності студентів, в т. ч. ігрових [5]. Одним з таких методів на нашій кафедрі є проведення фармакологічної вікторини на певну тему. В цьому році запланована вікторина саме на тему “Засоби, що впливають на систему згортання крові”, щоб поглибити знання студентів $з$ цієї життєво важливої теми. Такий метод навчання сприяє створенню емоційно-піднесеної атмосфери, засвоєнню матеріалу за допомогою насиченої форми його відтворення. Під час проведення вікторини в неформальній обстановці студенти-гравці презентують свої знання та вміння, отримані на лекційних та практичних заняттях та поглиблені в процесі підготовки до вікторини, а студенти-глядачі мають змогу ще один раз додатково повторити певний матеріал. Крім теоретичних питань, обов’ язковими є конкурси, що потребують не лише знань предмета, а й вимагають творчого підходу до реалізації поставленої мети, що відповідає основному завданню вищої освіти, яке полягає у формуванні творчої особистості фахівця, здатного до саморозвитку, самоосвіти, інноваційної діяльності.

Висновки. Отже, в сучасних умовах невпинного розвитку фармакологічної науки і постійного оновлення арсеналу лікарських засобів та груп препаратів, а також враховуючи непросту ситуацію в нашій країні, вивчення теми “Фармакологія засобів, що впливають на систему зсідання крові” $є$ важливим розділом медичних знань, необхідним для формування майбутнього лікаря.

3 метою покращення рівня підготовки студентів та надання додаткових можливостей самостійного опанування предмета абсолютно необхідними стають узагальнюючі підходи, використання графічносхематичних матеріалів, а також окремий акцент на самостійне опанування студентами особливостей дії та застосування окремих препаратів із залученням креативних підходів (брейн-рингів, вікторин), а також усних та стендових доповідей. 


\section{Список літератури}

1. Мороз В. М. Проблеми та перспективи вищої медичної освіти у реалізації Національної стратегії реформування системи охорони здоров’я України / В. М. Мороз, Ю. Й. Гумінський, Л. В. Фоміна // Проблеми та перспективи вищої медичної школи у розробці та реалізації національної стратегії побудови нової системи охорони здоров’я в Україні на період 2015-2025 рр. : тези доп. навч.-метод. конф. - Вінниця, 2015. - С. 3-6.

2. Балуєва О. В. Формування стратегічних напрямів діяльності вищих медичних навчальних закладів, спрямованих на удосконалення підготовки медичних кадрів / О. В. Балуєва // Державне управління: удосконалення та розвиток. - 2013. - № 12. - Електрон. ресурс., доступ : http://www.dy.nayka.com.ua.
3. Король А. Д. Диалоговый подход к организации эвристического обучения / А. Д. Король // Педагогика. 2007. - № 9. - С. 18-25.

4. Про вищу освіту: Закон України від 1 липня 2014 р. № 1556-VII [Електронний ресурс]. - Режим доступу : http://zakon4.rada.gov.ua/laws/show/1556-18/ print1392304548710695.

5. Ковальчук О. Дидактичні ігри як метод активації навчально-пізнавальної діяльності студентів у процесі вивчення педагогіки / О. Ковальчук // Вісник Львівського університету. Серія педагогічна. - 2004. Вип. 18. - С. 89-97. 